\title{
慶長十年再建の相国寺法堂について \\ THE RECONSTRUCTED HATTO OF SHOKOKU-JI OF 1605
}

\author{
木 村展子* \\ Nobuko KIMURA
}

The hatto of Shokoku-ji reconstructed by Hideyori in 1605 is of the utmost historical importance being the oldest and largest extant example of its type. Despite a shortage of lumber and various problems involving logistics,the building was completed in one year and became the exemplary model of subsequent hatto architecture. Its success as an architectural design lies in the fact that it was both large enough for the performance of religions rituals and rationally determined so that unnecessary elements were eliminated (i.e. it was both functional and economically efficient.)As a result, it came to represent a new kind of internal space.

Keywords: Shokoku-ji, hatto, Toyotomi Hideyori, Zen, Momoyama era 相国寺, 法堂, 豊臣秀頼, 禅宗, 桃山時代

はじめに

相国寺は臨済宗相国寺派の大本山で、足利義満が沓徳二年 (1382)に創建し京五山の第二位に位圈した名刹として有名である。 創建当時は仏殿・法堂・三門などはもちろんのこと七重大塔をも備 える大伽藍を持ち、数多くの塔頭を抱えていた。しかし、その後数 度にわたる火災によって、現在は堂宇もわずかとなり寺地も大幅に 減少している。そのようななか法堂は現存する法堂の中で最古かつ 最大の法堂として唯一重要文化財に指定されている。この法堂は慶 長十年 (1605)に豊臣秀頼が再興したもので近年修理工事が行われた !。また、秀頼は翌慶長十一年(1606)にも南禅寺法堂を再建してい る。秀頼は慶長三年より 100 近い寺社の造営を行っているが、この 2 棟はその中でも規模の大きな建築であり、さらに最も作事の集中 した時期に造営されている゙。

一方、鎌倉・南北朝時代の五山建筑に関しては横山秀哉氏、太田 博太郎氏、川上貢氏、関口欣也氏、永井規男氏などによる詳細な論 考があるが、五山寺院は中世に度重なる火炎に遭い、室町後期に 抢ける詳しい状涚はわかっていない。近世に入って禅宗寺院の多く が復興されるが、鎌倉・南北朝時代の五山建筑とは構造形式が大き く異なっていることは周知であろう。すなわち法堂においては身舎 梁間が三間から四間になり、立断面では 2 階建てから裳階付となっ
ている。また、三門、仏殿、法堂ともに内部身舍天井を全面鏡天井 とし、梁組を露出しない。相国寺は現存する最古の法堂として、室

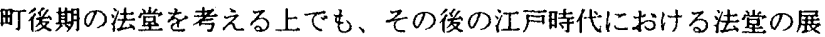
開を考える上でも非常に重要な建築だということができる。

相国寺法堂は造営に関する文書等が残っておらず、詳しい造営 経過などは判明していない。しかし、翌年に造営された南禅寺法堂 は現存こそしないが、わずかながら造営に関する文書や記録の類が 残っている。それらを参考にしながら慶長十年の相国寺法堂の造営 事情を明らかにし、さらにその検討作業を通して相国寺法堂の建築 的意義を考察したい。

\section{1、歴史と現状}

\section{1-1. 中心脚藍の变墂}

まず、法堂、仏殿、三門を中心に、創建当初からの中心伽藍の変 僄について概観する（表 1）。

永徳二年 (1382) 十月、足利義満の発願により相国寺が建立され る4。開山には春屋妙菂が招請されたが、春屋は夢空疎石を勧請し て開山とし自らは第二世住持となった。十一月には法堂、仏殿の立 柱上棟が同時に行われる。至徳元年(1384)三月には「大仏殿」の立 柱が行われこの年に完成している。至徳三年 (1385)には三門が立柱 
表 1 相国寺法堂·仏殿·三門

造営年表

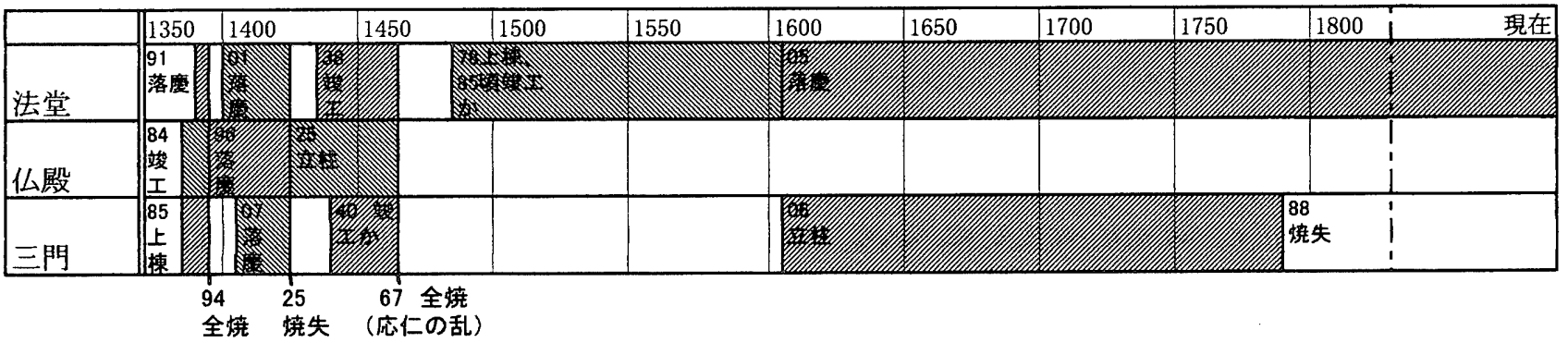

上棟、明徳二年 (1391) には法堂（法雷堂）が落成する5。こうして 次々寺観も整い、翌明徳三年には義満を迎えて総供養が行われる。 仏殿が 2 度立柱されているのは 2 棟建てられたのではなく、より規 模を大きくしての造営途中での設計変更だったのであろゔ。こう して約 10 年かけて広大な伽藍が築かれたが、総供養を行ったわず か 2 年後の応永元年 (1394) 九月二四日に直歳（しっすい）寮より出 火し、伽藍は焼失してしまう。同年十一月にまず仮設の仏殿と山門 の立柱が行われ、翌応永二年二月四日には本格的な仏殿（三世如来 大殿) の立柱が行われる。応永三年(1396)四月二日には法堂の立柱 六月二十三日には仏殿が落成、七月十日には三門の立柱と、義満の 低護の下、再建は急ピッチで行われた7。ただ法堂と三門の造営に は時間を要し、法堂は応永八年 (1401) に䇋エしたようである8。一 方三門はさらに時間を要し、応永十四年六月二十一日に蝬工してい る。ところが、応永三十二年 (1425) 八月再び火災にあってしまう9。 秉払の際に輪藏を法堂として用いているので、法堂も焼失したので あろう10。仏殿ははやくも同年十一月に立柱が行われる"1。永享七 年(1435) 八月には僧堂の立柱上棟、十月には三門の立柱が行われる。 法堂の着手は遅れて永㝇年四月に立柱、翌年の四月に落成する。 三門はさらに遅れて永卓十二年 (1440)に竣工寸る12。しかし、この あと応仁元年には「十月初三日卯刻、敵軍攻寺、従庫堂出火、七堂 并東方諸院・六鹿范一時為焦土、同四日午刻、西方諸院、始于雲頂、 終于大徳、皆毀兵矣」と中心伽藍はもちろんのこと塔頭寺院まで全 焼する ${ }^{13}$ 。

応仁の乱は十年余続き、文明十年 (1478)に至ってようやく法堂 の上棟が行われ、伽藍の再建が始まる14。しかし、文明十一年に再 び火災に遭うなど工事はなかなか進展しなかった15。いつ頃䇋工し たのかは明らかではないが、文明十七年(1485)には横川景三が住持 として入山し上堂説法を行っているので16、この頃までには少なく とも法堂 (無畏堂 $\left.{ }^{17}\right)$ は完成していた。しかし、三門は文明十七年 の横川景三の再住時にはまだなく18、その後も再建されたとは考え にくい19。また、仏殿は再興されなかったようで、延徳二年 (1490) 正月二十三日に亀泉集證が将軍義視の質問に答えて「仮法堂一宇有 之、仏殿亦用之」と述べているように20、法堂が仏殿を兼ねていた ようである。明応四年 (1495)になっても、景徐周麟が提網略で「雖 然仏末設殿僧末設堂」と述べているように、仏殿ばかりでなく僧堂 もなかったようである。そして、その状態はずっと続き、天文二十 年（1551）七月十四日に兵火によって火災に遭う21。法堂は焼失を 免れるが22伽藍の荒廃は免れず、再興が企図されるが果たせぬまま であった23。天正十二年(1584)、住持となった西笑承兌が中心とな
って再興を図り、慶長十年 (1605) 豊臣秀頼によって法堂（無畏堂） が再建され、綂いて翌慶長十一年 (1606)には徳川家康によって三門 が再建される。しかし、天明八年(1788)正月の大火によってほとん どの堂宇が焼失してしまう24。中心伽藍で残ったのは栜使門と法堂 のみであった ${ }^{25}$ 。文化四年 (1807)に方丈、庫塞、開山塔が、天保十 四年 (1843)に鐘楼が再建されるが、寺勢の衰えは避けることができ なかった。

\section{1-2. 構造形式}

構造形式は析行五間梁間四間の一重裳階付の入母屋造で、堂内 は四半瓦敷で中央に須弥壇を設け須弥壇上後方には本尊を安置する。 天井は身舎部分には板天井を張り裳階部分は化屋根裏とする。な お、身舎の天井部分には狩野光信による「蟠龍図」が描かれている ${ }^{26}$ 。

小屋組は梁間に二通りの大梁をかけ、桁行梁は三通り入れ大梁 上で繁ぎ、柱を立てず堂内を広い空間とする。堂内には身舎柱が林 立するが、主に北側の柱にはゆがんだ柱が目立つ。

須弥㙵は当初から設けられていて、本尊の䣋迦如来と迦葉、阿 難尊者が安置されている。須弥壇背面後壇には普庵禅師の位牌を安 㯰する。裳階背面の東脇壇には、足利義満、大権修理菩薩、西脇壇 には百丈、臨済、夢空、達磨像と歴代住職の位牌を安置する。本来 法堂は住持が上堂説法する場であり須弥壇ではなく法座とすること から、相国寺法堂は当初から仏殿との兼用を前提に建てられたもの であることがわかる。

現存している五山および同程度の規模を持つ臨済宗寺院の法堂 には次のようなものがある。（天龍寺法堂は僧堂を移築したものな ので除外した)

大徳寺法堂 寛永十三年 (1636) 桁行五間・梁間四間

妙心寺法堂 明暦二年 (1656) 桁行五間・梁間四間

建仁寺法堂 明和二年 $(1765)$ 桁行五間・梁間四間 27

建長寺法堂 文化十一年(1824) 桁行三間・梁間三間

全て一重裳階付の入母屋造であり、いずれも相国寺と同様、堂 内は四半瓦敷で天井は身舍部分には板天井を張り裳階部分は化精屋 根寒とする。また、相国寺の翌年に建てられた南禅寺法堂は、川上

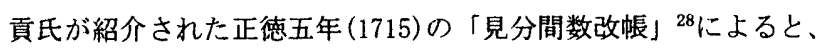
「間 $\times$ 七・五間、四方雨打一・五間宛」と相国寺の「十四間 $\times$ 十三間」よりやや規模が小さいものの、やはり一重裳階付で、なお かつ狩野信の蟠龍図が天井に描かれていたというから ${ }^{29}$ 身舎部分 は鏡天井であったに違いない。以上のように相国寺法堂以降は一重 
裳階付・身舎全面鏡天井という形式を踏襲している。

\section{2. 造営事情}

\section{2-1. 造黨経過}

1ー1で示したように、現在の法堂は創建以来 5 回目の造営にな るものである。その造営経過について考察する。

室町後期には、京都の禅宗寺院はいずれも戦乱によってすっか り疲幣していた上に、後ろ盾であった足利幕府の勢力も衰え、堂宇 すら满足に造営できない状況が続いていた。そのような中で登場し た豊臣家という巨大な権力は、彼らにとって利用価值の大きいもの であったに違いない。同時に、彼らの中国に対する樑い素養は豊臣 秀吉の対大陸政策になくてはならないものであった。特に相国寺長 老の西笑承允は秀吉と近しく、秀吉の対外政策に深く関わっていた

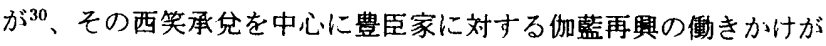
行われた。まず、西笑承兌誘吉に造営の願を出していたようで、 天正十七年に前田玄以が破壊された塔頭を見て回っている31。しか し、秀吉は方広侍大仏殿を造営する間、他の寺社の造営を禁止した 32。結局、法堂は秀吉の死後、秀頼によって慶长九年(1604)に着工 され、同年十一月十四日に立柱 ${ }^{33}$ 、翌慶長十年 (1605) 十月八日に落 慶法要が行われた。造営決定に至った詳しい事情は定かではないが、 『慶長日件録』慶長十年五月十九日の条には「相国寺法堂見物、過 半出来、柱等奇麗警目畢、近日又鐘楼出来云々、豊光寺当代依為㷌 依僧、寺院繁盛異他寺者也」と記され、造営の途中の様子がうかが われる。そして、十月八日に落慶法要が行われるがたいんん盛大な ものであった ${ }^{34}$ 。

このように秀頼による法堂の造営は 1 年で竣エしたが、翌年の 南禅寺法堂も同様であった。南禅寺も忘仁の乱により堂宇は灭㸁に 帰したが、文明十一年(1479)に法堂が再建された 建てられなかったようで法堂が仏殷を兼ねていたと考えられる36。 しばらくその状態が続くが、相国寺の西笑承允と共に秀吉の対外政 策に深く関わった南禅寺長老の玄固霊三により、慶長九年（1604） 九月に造営の願いが片桐貞隆を通して秀頼にだされ、十月には造営 決定の報が伝えられている37。，そして慶長十年(1605) 七月末に着工、 翌慶長十一年七月五日に落慶法要が営まれている ${ }^{38}$ 。

この他近世初期の京五山の各寺院では、応仁の乱以降荒廃して いた伽藍の整備が行われている。まず、相国寺では法堂に続いて三 門が徳川家康によって再興される。慶長十年九月二十八日に材机の 調達を始め、翌慶長十一年二月十五日に立柱を行っている ${ }^{39}$ 。落慶 法要は慶長十四年四月三日である。ただしこの三門は天明八年 (1788)の大火で焼失し現存していない40。また、南禅寺は古い三門 があったがィ、寛永五年 (1628)に藤堂高虎の寄進で建て替えている。

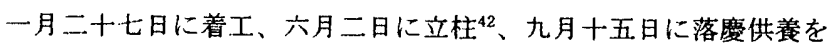
行っている ${ }^{43}$ 。天竜寺は、応仁の乱で法堂・仏殿共に焼失した後、 慶屒三年 (1598)に法堂を再建している ${ }^{44}$ 。建仁寺は、天文二十一年 (1522)の兵火で法堂・仏殿ともに焼失したが、安国寺恵隐が東福寺 の茶堂を移築して仏殿としている15。なお、東福寺は洛中から離れ たところに位置しているということもあって、応仁の乱では焼失せ ず南北朝時代の伽藍が残っていだ6。

しかし、このあと武家などからの寄進はなく、筧永十一年 （1634）に家光が上洛した折に、五山はそれぞれ久いている堂宇の再
建を願い出るがかなわなかった 47 。それぞれ願い出た堂宇は、南禅 寺が仏殿、天龍寺が三門、相国寺が仏殿、建仁寺が三門、東福寺は 「七堂并開山堂御修復」であったが、いずれの堂宇も江戸時代には 再興されることはなかった。

\section{2-2. 材木事情}

修理工事報告書によると、身舎柱 18 本のうち檜が 16 本、櫒が 2 本である。長さは 27.77 尺から 27.90 尺まであるが、「長さに余裕 がなかったのか、先細りの柱が多く、18 本のうち柱頂部が頭継さ れていたり運搬穴が埋木されていた」という。

相国寺法堂作事における材木事情について書かれた記録類は無 いが、南禅寺法堂作事に関しては、片桐且元から南禅寺の金地院崇 伝へ送った次のような書状がある48。

態令申候、法塔材木之儀、大坂中其外方々相噐候へ共、四間四 尺之柱と大引物少不足二候、誂候八八来年五月ならて八参間敷 由候間、少不足之分八堪忍候て、当年相立可然と存專申侯へ八、 四間武尺迄之木八有之事候条、(後略)

大坂には四間四尺の柱がなく、調えようと思うと来年五月になるの で、今ある四間二尺の柱で建ててはどうか、と進言しているのであ る。一間を 6 尺とすると 28 尺の柱はないが 26 尺の柱であれば大坂 にあるということになる。一間を 6.5 尺としても 30 尺の柱はない が 28 尺の柱であれば大坂にあるということになり、当時の豊臣家 の資材の所有状况を示している。おそらくこの書状は着工される寸 前の慶長十年に書か冯たものであり、相国寺法堂の身舎柱の状態を 裏付けるものである。

この慶長十、十一年というのは秀頼の 100 近い寺社造営のなかで も最も作事が集中した時期である49。そのうち慶長十年(1605)十一 月十七日に再興された醍醐寺西大門の場合には、慶長八年 (1603)二 月に片桐且元に造営の願いを申請し、慶長十年七月に再興が決定す る50。七月二十二日には材木が注文され、八月十三日釿始、その後 礎石探しにやや手間取ったようで十月十二日礎突、同二十一日立柱 となるが、山上伽藍と同様「大坂ニテ悉木作了」であった。材木は 多くが檜であるが、柱は翌年の春まで待たないと檜が用意できず栂 になったという5゙。相次ぐ作事で材木が不足していたことがうかが える。

もっとも材木不足は豊臣家に限ったことではなかった。慶長十 一年 (1606)に相国寺三門が建てられた事は前述したが、このときも 五間の柱を希望したがなかなか手に入らず、慶長十年中の立柱は断 念している52。南禅寺三門もどの程度の材木を用いたかは明らかで ないが、『本光国師日記』によると藤堂高虎が三門造営をすること を申し出たのは寛永三年四月二日のことであるが53、高虎の南禅寺 に宛てた書状によると材木が初めに南禅寺に届いたのは寛永四年五 月である ${ }^{54}$ 。さらにその後も少しずつ送り届けられ、材木の過半が 届くのはやっと十二月になってからである55。つまり材木の調進に 7 月を費やしたことがわかる。禅宗の中心伽藍は中世より小さく なったとは言うものの ${ }^{56}$ 、やはりいずれも規模が大きく、材木の調 達には苦労が伴ったことがうかがわれる。

秀頼が慶長十四年以降、方広寺以外の寺社造営を汪とんど行わ なくなるのは、政治上の理由もさることながら 57 、この材木不足も 大きな要因であったと考えられる ${ }^{58}$ 。 


\section{2-3. 缡野采と谴管料}

相国寺法堂の造営に関する文書は残っていないが、『鹿苑日 録』慶長九年十一月十四日の条に「同途シテ赴法堂、見柱立、文殊 院於円光門外相逢、十一本見相立、」、鹿長十年四月八日の条に 「其内高野法堂奉行僧衆・少年福千代卜云少年酒半来・.」とあ り、文殊院樊譽をはじめとする高野衆が相国寺法堂の作事に関わっ ていたことがわかる。秀頼が造営した寺社のうち高野衆が関わって いたことが明らかなのは、鹿長四年 (1599)の若国廟、慶長五年 (1600)の方広寺と醍醐寺金堂、三十三間堂、㢄長八年 $(1603)$ の杲寺 金堂、慶長十年 (1605)の東寺東大門、南大門、康脣十一年(1606)の 南禅寺法堂である ${ }^{59}$ 。鹿長五年、関が原の戦いの後木食态其は隠遁 するが、東寺は真言宗の寺院であり文殊院勢管がその作享に関わっ たのは特に不思議ではない。しかし、相国寺と南禅寺の法堂作蹇に 関わっていることは注目すべきである。南禅寺法堂の作事でも、材 木の選定等の中心となっていたのは寺家大工の清左衛門であるが、 片桐且元が材木についての相談をするなど、ここでも文殊院勢罡が 閣与している ${ }^{60}$ 。

ところで相国寺法堂の再建には豊臣家から一万五千石の寄進が あったことが判明しているが、この金額を秀吉・秀頼の他の造営寺 社と比較する。

$\begin{array}{lr}\text { 相国寺法堂 } & 15,000 \text { 石 } \\ \text { 青厳渡寺 (全堂宇) } & 10,000 \text { 石 } \\ \text { 津島神社南門 } & 500 \text { 石 } \\ \text { 醍醐寺山上伽藍（3棟） } & 10,000 \text { 石 } \\ \text { 西宫神社 } & 1,072 \text { 石 } \\ \text { 筫面寺本堂 } & 733 \text { 石 } \\ \text { 勝尾寺本堂 } & 664 \text { 石 }\end{array}$

方広寺大仏殿（天正度 ） 83,000 石（供恙の費用を含む） 天正度方広寺大仏殿は別格にすると相国寺法堂の造営料の多さ がわかる。つまり相国寺法堂作事では特に建築経営の手腕が求めら れたのである。高野衆は方広寺を初めとする数々の大建篦を造営し てきている。相国寺法堂も南禅寺法堂も疲荆しきった京五山寺院は もちろんのこと、豊臣家の奉行・大工衆だけでは作敦を行うことが できなかったのではないか。

関が原合戦までは五奉行の一人で公家・社寺を管轄していた前 田玄以と応其の間に、前田玄以一未食忘其という関係が確かに存在 していた。前田玄以が総奉行、湌応其が作舸奉行、その下に下奉 行として高野鼻たちがおり、不食応其の圧倒的な組織力と建築経営 能力によって、秀吉の寺社に関する作學組織は機能していた しておそらくは、技術的には応其がつれてきた大仏大工たちが主導 していた。方広寺をはじめとする贾吉の作事では「钼員力を誇る軍 事的な生産組織と、寺院の持つ伝統的な生産組織とが一体化」 し62 豊国廟作事など秀吉の死後もしばらくは継続するが、态其の隐遁で 終舃を迎える。関が原合戦後、片桐且元が江戸幕府の摄河泉の国奉 行となるとともに、豊臣家の家老として豊臣家の作事の多くを統括 するが、片桐且元一文殊院勢笪という関係は明確ではない。結局、 秀吉に「木食の高野」と言わせたほどの、天正十三年(1585)の高野 攻め以来続いた秀吉と応其の密接な関係に代わるものを形成しえず、 夸吉の寺社造営において機能した作事組織は解体してしまうのであ る。そこには、一山を支配した応其とは異なり、文殊院勢譽の高野
山支配が順調ではなかったこともあったと思われる 「伝統的な生産組織」である高野竞に依存している限り、中世的な 組䌬から脱却できないのであり、脱却するためには「艻頼様大工」 達、すなわち応其が連れてきた大仏太工の源左衛門や法隆寺大工で 豊臣家の「御大工」となった藤右衛門、萂師寺大工であった喜多越 後守清次などが、秀頼配下の諸職人を一元的な檤の組織として再編 し、同時に寺社大工も含めた工匠の動員管理や工費監理などもする 武家御大工人変質しなければならなかった。しかしそれは徳川家御 大工の中井正清にしかなしえなかったのである゙5。このように、技 術的問題よりも秀頼の作事組織の運営的側面における管理者の不在

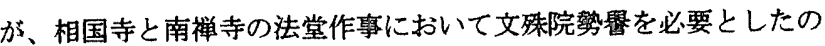
であり、それこそが秀頼の作事組織の限界だったのである。

\section{3．相国寺法堂の建筑的意䠛}

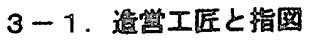

修理工事報告贯によると、栈唐戸に「此ハツタウツカマツリソ ロう王物大仏ノ大エナリ源左衛門タウリヤウナリ」という罩書があ り、造営に㙨わった工匠は大仏大工の源左衛門であるであることが わかる。源左衛門は唀頼御大工のひとりであり、醍醐寺の山上加藍 の作事に従事している ${ }^{65}$ 。この源左衛門が、方広寺作事の際に木食 応其が紀伊と大和からそれぞれ 10 人ずつ連れてきた、いわゆる 「大仏大エ」であることは醍期寺座主の義演も『義演准后日記』に 記しており ${ }^{66}$ 、当時源左衛門が大仏大工であったことは広く知られ ていた。また、繶く「ウチキモイリタンハラヤー郎ナリジワリヨハ ヤ一郎ツカマツリソロコノモノ、トコロワヤマトウチノカウリヨ

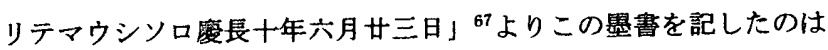
源左衛門配下の「肝朔」大工の「や一郎」であったようであるが、 その出身が大和宇智郡丹原（現在の奈良県五條市）であると記すこ とから、源左衛門の出自も大和であった可能性は高い。宇智郡の池

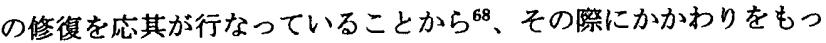
たのかもしれない。

ところで、豊臣㺯顐が費用を下行し、奉行も派遺した 100 件近 い作鼔を寺家・社家大工の関わり方からみると、大工や諸職人も派 望して作聂を行う場合（A方式）と、寺家大工や地元の大工が主体 となって作事を行う場合（B方式）の2 䧽類に分類する事ができる 69。この相国寺法堂の作事は「地割図」の作成を「队一郎」が行っ ていることから、豊臣側大工が主体的に作事に参加するA方式であ ったことがわかる。なお源左衛門は翌慶長十一年の醍醐寺山上伽藍 の作铎でも開山堂・五大堂・如意輪堂すべての地割を行っている。 䤐勡寺山上伽藍もA方式であったが、指図は「山上学侶」が大坂へ 持っていっている。また、同じく $\mathrm{A}$ 方式の北野天渵宮の作事（慶長 十二年)でも指図は松梅院が自ら踾付けている70。㴍々な宗教行事 の行なわれる建造物では機能的な側面は非常に重要であり、醍醐寺 と北野天満宫の場合は機能に深く関わる平面計画は寺家、社家側が 行っていた。相国寺でも㷐置にわさわさ記していることを考えると、 䇺臣側は地割のみを行った可能性が高い。そうであれば平面計画は 相国寺側、立断面計画は豊臣側が行ったことになる。

\section{3-2. 平面と立面について}

建長寺や東福寺の法堂は、銠倉時代には大規模な重層建筑であ 
った事が判明している71。しかし、前述したように五山寺院はその 後何度も再建が繰り返され、法堂がどのような形式の変遷をたどっ たのかは明らかではなく、正長元年(1428)に再建された東福寺法堂 が裳階のつかない単層であることが判明している以外、室町時代に 建立された法堂の立面は全く判明していない。また中世の平面が判 明している五山の法堂は、創建以来 2 度目の造営となる嘉暦二年 (1327)の建長寺、正長元年の東福寺、忘仁以前と思劢る天龍寺だ けであるが、いずれも身舎は析行五間、梁間三間である。

室町後期になると、京五山では多くの堂宇が応仁の乱で焼失し、 建仁寺のように応仁の乱で焼け残ってもその後の天文の乱で焼失し ている。その結果、室町末期には五山寺院といえどもかつての面影 はなく、多くの寺院で法堂と仏殿を兼用していたようで、相国寺は もちろん南禅寺や天龍寺でも忘仁の乱以降仏殿は建てられていない。 室町後期から近世初期にかけての五山寺院における法堂もしく は仏殿の状況をわずかな記録から類推すると、天龍寺法堂は慶長三 年 (1598) 七月二十六日に上棟する ${ }^{72}$ 。元治元年 (1864) 薩摩藩の兵士 によって焼かれてしまい現存していないが73、その大体の大きさは 先の「見分間数改帳」によって判明している。「六間 $\times$ 六間 四 方廂一・五間宛」と、秀頼再建の相国寺法堂や南禅寺法堂に比べて かなり規模が小さく、正方形平面であったことがわかる。この時期 の東福寺を除く京五山及び大徳寺・妙心寺では、いずれも法堂と仏 殿が兼用されている。建仁寺は東福寺の茶堂を移築したものである が、文明十一年 (1479) 上棟の大徳寺法堂は東西六間半南北五間74、 文明十一年に着手された南禅寺法堂は慶長再建時よりも規模が小さ く ${ }^{75}$ 、天正十一年 (1583) 以前に建てられた妙心寺法堂（兼仏殿）は 八閒五尺四方と天龍寺と同程度の規模であった ${ }^{76}$ 。慶長再建以前の 相国寺法堂も亀泉集證が「仮法堂一宇有之」と言っていることから 不十分なものであったに違いない。秀頼の建てた相国寺法堂が、そ のころ未だ威容を誇っていた東福寺法堂には及ばないものの、それ までの法堂兼仏殿よりも如何に規模の大きなものであったかがうか がえる。

まず、立断面について検討すると、相国寺以降の法堂は一重裳 階付、内部は身舎部分が全面鏡天井となっている。慶長三年に建て られた天龍寺法堂は「四方廂」と記されているが、『都名所図会』 77をみると裳階付となっている。そして、亀泉集證が「仮法堂」と 呼んだ文明十年上棟の相国寺法堂は「雨打」があり裳階付であった 78。また天正十一年 (1583) 以前の妙心寺法堂（兼仏殿）も「見分間 数改帳」によると裳階付である。一方『匠明』堂記集の「法堂之 図」は単層となっている。ただ、「法堂之図」と記した隣に「同徒 仏殿共云リ」とあり、仏殿と法堂の共用が広く行なわれていたこと をうかがわせる。『愚子見記』社頭伽藍には中国では仏殿・法堂と もに裳階付とするが、日本においては寺や施主の経済力によって単 層にするか裳階付にするかの定めは無いとしている。

現存する中世の仏殿の多くが一重裳階付であり、五山仏殿に淮 じる規模の不動院金堂も一重裳階付であることを考えると、室町後 期に仏殿と兼用する中で、法堂も一重裳階付に変化していったと考 えることは可能であろう。

内部天井に関しては、相国寺以前の法堂については全く史料が なく、『匠明』も『愚子見記』も言及していない。時代の下る『諸 堂社絵図』（宝永四年 (1707)～寛延元年 (1748) 頃成立、大谷出雲基
矩著）になると、法堂は正面五間で妻側が四間のものと五間のもの があるが、いずれも一重で、庆部分は化栍屋根裏、身舎部分は全面 鏡天井となっている。中世に法堂内部の天井がどのようになってい たかは不明であるが、少なくとも重層であった時期には身舎は全面 に天井が張られていたことは間違いなく、相国寺以降の法堂もその 伝統を受け継ぐものとも考えられる。しかし、そう考えると寛文五 年 (1665)の大徳寺仏殿、文政十年(1827)の妙心寺仏殿が身舎部分を 全面鏡天井とすることに説明がつかず、鏡天井は時代的な傾向であ るとも考えられる79。さらには、寞文九年(1669)の泉涌寺仏殿や承 応元年 (1652)の南宗寺仏殿が中央方一間鏡天井と中世仏殿に近い形 をとることを考えると、その他の要因も考えなければならないが、 現時点では検討の材料が不足しているのは否めない。

次に、平面について検时寸ると、相国寺以降の近世の法堂と中 世の法堂の大きな違いとして、梁間が三間から四間になり奥行が深 くなることがあげられているが80、実際は柱間が小さくなるので身 舎奥行としてはそれれぼの変化はない。中世の法堂の平面が判明し ているのは建長寺、東福寺、天龍寺であるが、建長寺と東福寺は来 迎柱が身舎柱筋にあることがわかっているが、天龍寺は法座位置が 判明していないので身舎柱の梁間方向の長さを記すと、建長寺四丈 二尺、東福寺四丈八尺六寸、天龍寺四丈七尺である。一方現存寸る 近世の法堂の前面身舎柱から来迎柱までの奥行は相国寺四丈四尺二 寸、大徳寺三丈九尺四寸、妙心寺四大六尺一寸であり、中世の法堂 と大きな差はないことがわかる。それよりも、近世の法堂と中世の 法堂の大きな違いは、桁行は五間と変わらないので柱間が小さくな った分、身舎析行方向がずいぶんと狭くなったことである。

法堂に㧍ける最も重要な法会である住持の上堂説法や頭首の秉 払の際、大衆は㕍行側立、即ち東西に分かれ相対して整列して聴聞 するが8!、義満期の相国寺には 800 人に及ぶ僧衆がいたが、応仁の 乱後は 200 人になったという ${ }^{82}$ 。近世に入るとさらに大衆は減り、 慶長二年には沙喝を含めて 110 人であった 83 。大衆の減少によって 東西に大きな空間が必要ではなくなったのである。また、上堂や秉 払の時には座前問訊 ${ }^{84}$ を行うが、これは法座前、法堂正面の入側柱 で行う。これ以外にも法座前方の空間を使用し、問禅や秉払などの 法会を行う際にはこの前方の空間は非常に重要であった ${ }^{85}$ 。亀泉集 證が「仮法堂」と称していたのは、法堂が小さくて十分な法儀が行 えなかったからではないか。そして、この慶長造営では梁間方向を 四間にして正面から法座までの奥行を梁くすることによって、法儀 の執行に十分な内部空間を取り戻し、なおかつ大衆が诚少して必要 のなくなった東西の空間を省いたのである。これによってかなり造 営費用の削减が可能になったに違いない。つまり慶長十年造営の相 国寺法堂の建築史的意義は、結果的に機能的でなおかつ経済的な法 堂を作り出したことにあるといえる。

\section{おわりに}

秀頼の相国寺法堂の再建は材木不足と建築経営に悩みながらも 1 年で竣工し、法堂はその後の法堂建策の規範ともなった。それは析 行五間梁間四間という平面が機能的であり経済的であったからであ ろう。しかし、一重裳階付・身舎全面鏡天井という立断面は『匠 明』をはじめとする木割書にはなく、どうしてそのような形式が採 用されたのかは明らかではない。豊臣側大工が立案したと考えると、 
機能的な理由からではなく構造的問題、または意匠的問題などが予 想される。特に、一重裳階付に関しては経済的な問題と意匠的な問 題があったのではないかと考えられる。というのも秀吉は天瑞寺と 祥雲寺という二つの禅宗寺院を作ったが、天瑞寺は大徳寺内の塔頭 ということで客殿のみであったようだが防、祥雲寺の法堂は重閣で 二階があったことが判明している ${ }^{87}$ 。やはり当時でも法堂建策の理 想は二階堂だったのではないか。しかし、秀頼は摄河泉五十二万石 の一大名となっていた上に、数多くの寺社造営を行っていたため、 経済的な理由から一重にせざるをえなかった。それでも東福寺のよ うに全くの単層よりも立派な外観となる裳階付を選択したのではな いだろうか。

一方、身舍を全面鏡天井とすることについては現時点では不明 な部分が多く、今後の課題としたい。

\section{嘻}

'『重要文化財相国寺本堂（法堂）・附玄関廊修理工事報告番』京都府教育 委員会 1997 年

拙稿「豊臣秀頼の寺社造営について」（日本建築学会計画系論文集 第 499 号 1997 年) なおその後の調查によって山城では相国寺鍏楼、宝稍寺、禅 林寺本堂、由岐神社本殿、その他の地方で産田神社仁王門、王布良天王社、 多贺大社を造営していることが判明した。さらに磨長五年には三十三間堂 を修理している。それらを含めると秴頼による寺社・稩梁の造営数は 96 件 となる。

3中世禅宗寺院に関しては先学による数多くの優れた論考がある。本稿で索 考にしたものだけでも横山秀哉氏の『弾宗伽藍殿堂の研究』（1958 年）、 太田博太郎氏の『日本建築史論集四社寺建築の研究』（岩波書店 1986 年)、川上頁氏の『椫院の建筑』（河原書店 1968 年）、仲世の寺院建

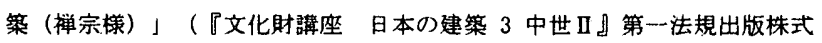
会社 1977 年)、「三瑟寺伽藍古図について」「古絵図にみる禅寺の建 策」（『建築指図を読む』中央公論美術出版 1988 年）、『日本建築史論 考』(中央公論美術出版 1998 年)、関口欣也氏の一連の「中世禅宗様建 築の研究」（日本建築学会論文報告集第 110 号、第 111 号、第 115 号、第 116 号、第 118 号、第 119 量、第 121 号、第 123 号、第 128 号、第 129 号、 第 149 号、第 150 153 号)、永井規男氏の「中世五山に挍ける庫院とその 変容」（建策史学第 38 号 2002 年）などがある。

${ }^{4}$ 以下、創建時と 2 度目の度永年間の造営に閣しては「相国考記」上による。 (『相国寺史料』第 1 巻 思文閣出版 1984 年)

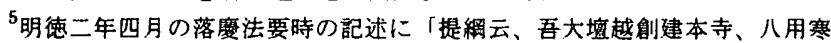
暑、殿堂巳境、最為後経営法堂、緗経数月、棟宇亦輸奐」とあり、最後仁 法堂が竣工したと思われる。七重大塔は総供荎の後、明徳四年に立杜が行 われている。〔「相国考記」上(『相国寺史料』第 1 巻 思文閣出版 1984 年)了

${ }^{6}$ 「空華日用工夫略集」永徳三年十一月二十六日の条に「仏殿・法堂二基立 柱上棟同時也」とあるが、その仏殿が竣工した記述はない。そして至徳元 年二月二十五日に「君日、姑侯仏殿落成云々」、三月十六日に「相国仏殿

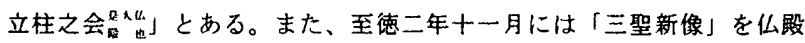
(覚雄宝殿)に安置している。

7 ただし、七重大塔は态氷七年 $(1400) に$ 雷によって焼失した後は、鹿苑寺に 移された。しかし、それも応永二十三年(1416)に再び雷火で焼亡する。 (看闢御記子応永二十三年正月九日の条)

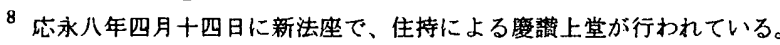

9 『看閶御記』応永三十二年八月十五日の条に「䦥、相国寺炎上所者、寺中

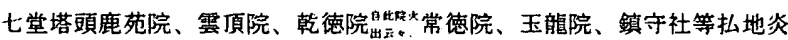
上。」とある。
10 「冬節諸頭首集払、以輪藏為法堂〕〔「相国考記 上〕(『相国寺史料』 第 1 巻 思文閣出版 1984 年) 了。また『看䦚御記』応永三十二年八月十 五日の条にも「残所者輪藏、大塔、裳寿院、大智院、大徳院、勝定院、慧 林院、大䗷院八ヶ所残了」とある。

${ }^{11}$ 『看開御部』応承三十二年十一月三日の条「閏、今日辰一点相国寺仏殿立 柱云々」。竣工した時期は明らかではないが、『看閏御記』にはこのあと 永章八年三月七日の条に相国寺仏殿の棟木に書か九た鹿苑院の名字の記事 があり、『陵凉軒日録』永享八年三月十二日の策に仏殿に脇侍を安圈する 記事があるので、承辛八年(1436)には仏殿が完成していたことは間違いな い。

12 『臀凉軒日録』に造営経過が詳しいが、三門の彩色のため洛中の絵師に扇 絵を提出させている。その結果土蔵に決定するのだが、士蔵は仏画や肖像 画なども描く膱業絵師であり、おそらく、東福寺三門上層内部のような彩 色が施されたのであろう。

${ }^{13}$ 『相国考記 中』(『相国寺史料』第 1 巻思文閣出版 1984 年)

14 『相国考記 中』（『相国寺史料』第 1 巻 思文閣出版 1984 年)

15 『実隆公部』文明十一年九月二十九日の条

16 『補庵京華新集』（玉村竹二編『五山文学新集』第 1 巻東京大学出版会 1967 年)

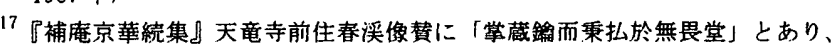
文明十三年の時点で法堂は「無畏堂」と呼ばれていたことがわかる。

${ }^{18}$ 『落凉軒日録』文明十七年四月二十七日の条。

${ }^{19}$ 忘仁の乱以降『落凉軒日録』『鹿苑日録』に、それまであった三門での施 餓鬼や㵶法、祈裙などの記事が全く見られなくなる。

20 『落凉軒日録』延德二年正月二十三日の条。また「又日、乱後諸五山皆廃 壊否。思云。皆廃壦。就中相国寺第一之廃壊也。」とも記さ机、応仁の)乱 での惨状がうかがえる。

${ }^{21}$ 『公卿補任』に「天文二十年辛亥・・七月十四日相国寺放火乱妨等。」と ある。また『史料総踥』巻十「天文二十年七月十四日細川晴元の武将三好 正勝及び香西元成等、丹波上り京都に入り、相国寺に陣す、是日、三好長 度の武将松氷久秀等、攻めて、之を敗走せしむ」とある。

22 『鹿苑日録』には永禄・天正・文禄年間を通して法堂の記事が多数照めら れる。

${ }^{23}$ 『鹿苑日録』に、建仁寺と南禅寺に宛てた永禄三年付の法堂寄付受取の文 案が揭截されている。

24 『参餟尞日祀』天明八年二月の条（維明周㘴笔録）

天明八年正月晦日、寅之半刻、河東新道失火、丑寅八風強ク、卯之 上刻、河西人飛、自是列風猛火、時々変化、西南北延焼、丑之刻

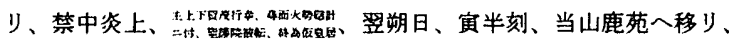
総門、山門、方丈、莗裡、侍真尞、祖塔、宝塔、毘沙門堂、鐘楼并 山中二一々院、至于辰刻為灰橴、此日至于申刻、鞍馬口安居院边野 八焼盘而、火始而减ス、西八限千本习、南至七条、為一望焦士、 とかなりの大火であったようである。

${ }^{25}$ 天明八年 (1788)の相国寺末寺帳によると塔頭 48、十刹 3、末寺 71 、孫末寺 4 を有しているが、一方ではこの時すでに 49 塔頭、1 諸山、12 末寺、7 弶 末寺の計 69 力寺に及ぶ敗壊寺院があったことが報告されている。（『国 史大辞典七』相国寺の項 吉川弘文館 1986 年)

26 狩野永納瀷『本朝画史』延宝四年 (1676) 頃成立、元䘵四年 (1691) 刊行（笠 井昌昭他訳注『訳注本朝画史』同朋舎出版 1985 年)

${ }^{27}$ 『京都府の近世社寺建案』(京都府教育委員会 1983 年)では伀殿として いるが、小出祐子「明和二年における建仁寺法堂再建と境内の開発につい て」（日本建筑学会計画系論文集 第 543 号 2001 年）によると建築当時 は主に法堂と呼称されていたので、本稿では法堂として报う。

${ }^{28}$ 川上貢「東福寺の伽藍と塔頭」（『日本建築史論考』第二編五 中央公論 美術出版 1998 年)

29 前揭噇 26

30 辻善之助『日本仏教史 近世編之一』岩波書店 1952 年

31 『鹿苑日䎑』天正十七年三月二十九日「民部卿法印寺中破壊之寺一匝】

32高野山文書 360. 豊臣秀次朱印状（『大日本史料 家わけ第一 高野山女 書之二』続宝简集 38)

それどころか材木の徵発を行なっており『鹿苑日録』文禄元年九月二十一 
日の条に

大工来。午時自民法有使。於寺中大材木求㯰。又新伽藍建立之用意在 之否。即以能智寺中江触之。

とあり、又翌日には

蓋材木之一件、即以一書呈玄印法印。書日、於寺中材木大物之柱等過 分仁無之云々。

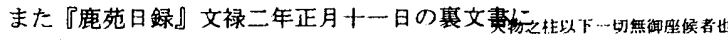
寺中材木之儀。蒙仰候。則寺中相触候。㜀藍建立仕儀無之候。其外 大物之柱以下過分に用意申儀無御坐候者也。

という文禄元年九月二十一日に前田玄以（民部卿法印）にあてた文案があ る。

33 『鹿苑日録』慶展九年十一月十三日、十四日の条

34 『鹿苑日䩮』慶長十年十月八日の条

35 睛富宿祥記』文明十一年八月五日の条「南禅寺法堂今日事始云々」。な お、态仁の乱で焼失するまでの南禅寺伽藍に関しては太田博太郎『社寺建 策の研究』（『日本建筑史論集而』岩波書店 1986 年）五山の建筑・六、 南禅寺に詳しい。

${ }^{36}$ 桜井景雄『南样寺史』上 法藏館 1977 年

37 『南椫寺文畫』中巻 $333 、 335$ 片桐賁隆書状

38 『鹿苑日錄』慶长十一年七月五日の条

${ }^{39}$ 『鹿苑日録』慶长十一年二月十五日の条

${ }^{40}$ 『参暇㬌日記』天明八年二月の条

${ }^{41}$ 『本光国師日記』寛永五年二月腤日「十九日より古山門こわし候」

42 『南禅寺文書 下巻』407 藤堂高虎書状、『本光国師日衭』宽永五年五月 十六日の条

43 『本光国師日記』寛永五年九月十五日の条

${ }^{44}$ 太田博太郎『日本建筮史論集吕 社寺建築の研究』（岩波書店 1986 年） 五山の建筑 七、天竜寺 なおこの法堂は、元治元年(1864)に兵火によって焼失している。

${ }^{45}$ 安国寺恵酸は慶長三年十月東福寺に住し、慶長五年の関が原合戦のあと刑 死しているので、移築は慶曼三年から五年の間である。（辻善之助『日本 《教史 近世篇之一』岩波書店 1952 年)

${ }^{46}$ 川上貢『日本建築史論考』（中央公論美術出版 1998 年）第 2 編 寺院建 筑の研究 5. 東福寺の伽藍と塔頭

${ }^{47}$ 宽氷度大鄭院様御上洛旧部写（『相国寺史料第 2 . 巻 相国寺史稿 2 』思 文閣出版 1986 年)

48 『南禅寺文書 中巻』339片桐且元書状

49 前揭註 2

${ }^{50}$ 『義演准后日記』(『大日本史料』磨長十年十一月十七日)

${ }^{51}$ 『義演准后日記』鹿長十年九月十六日の条（『大日本史料』慶長十年十一 月十七日)

52 「西笑和尚文案」(『大日本史料』慶唇十一年二月十五日)

53 个良長老、竹西堂一一紙二書状遗 由二候故、」（『本光国師日記』寛永三年四月二日の条）

54 『南禅寺文書 下巻』404 临堂高虎書状

55 『南禅寺文書 下巻』 405 藤堂高虎書状

${ }^{56}$ 川上貢『日本建筑史論考』（中央公論美術出版 1998 年）第 2 編 寺院建 築の研究 5. 東福寺の㚳藍と塔頭

${ }^{57}$ 产是十四年ごろまでには徳川氏による豊臣包囲網が完成していたという。 (藤田達生「徳川将軍の創出」年報中世史研究 25 号 2000 年)

${ }^{58}$ 藤長十三年頃から秀頼は大仏殿再興のため、各地から材木を集めている (『大日本史料』磨長十四年正月是月）。慶長十五年六月十二日には堘始、 八月二十二日には立柱を行っているのでその頃には材木がある程度集まっ ていたのだろう(『大日本史料』璴長十五年六月十二日)。

${ }^{69}$ 拙稿「豊臣秀頼の作事体制について」（日本建築学会計画系論文集 第 511 号 1998 年)

60 『南禅寺文書 中巻』340片桐且元書状、341，342 文殊院勢誉書状

${ }^{61}$ 慶辰三年 (1597)の醍䑚寺下伽藍作事では伽藍は木食态其、門跡赛殿は增田 長盛がそれぞれ作事奉行となっている（『義演准后日記』磨長三年二月二 十三日の条）。事績からみても応其は寺社建築の造営のみを担当したと考 えられる。
62 『新建築学体系 44 建築生産システム』彰国社 1982 年

${ }^{63}$ 関が原合戦のあと家康は行人の勢譽に応其のあとを相続させ、高野一山の 支配をさせようとするが、学侶方より不満が噴出し、慶长六年 (1601) 京都 に出て訴勏を起こした。この学侣方と行人方の争いは十七世紀末まで繶く。 （宮坂宥勝・佐藤任『新版高野山史』心交社 1984 年）

${ }^{64}$ 応其の隠遁は中世後半から起こってきた十款聖による社寺造営の終㻛とい える。座を解体したのは紛れもなく織豊政権であり、十款聖の活動は建築 生産を既存の体制から解き放つ機運を作り出し、秀吉と木食応其による数 多くの造営はその㥒結点であった。しかし、秀吉も秀頼も寺社大工や禁員 大工などを再編成したわけではなく、併存していたに過ぎなかった。そう いう意味では城普請において近世的であったとしても、秀吉の寺社造営に おける作事組織は過渡的なものであった。集権的で整備された作事組織は 町大工・問閶大工・新興大工などあらゆる大工の再編成を進め、一元化し た中井正清のもとに成立したのである。

65 前揭註 59

66 『義演准后日記』慶長十年十一月九日の条（『大日本史料』度長十一年六 月二四日)

${ }^{67}$ 墨書の判読は神戸大学助手森田竜雄氏（日本中世史）のお世話になった。

68 『高野山文書』(『大日本古文書』家わけ第一) 491 諸寺諸社造営目録

${ }^{69}$ 拙稿「豊臣秀頼の作事体制について（日本建築学会計画系論文集 第 511 号 1998 年)

70 『北野社家日祀』慶長十二年七月二十六日の条

${ }^{71}$ 太田博太郎『日本建築史踰集田 社寺建勧の研究』五山の建築 三、東福 寺 四、建仁寺 (岩波書店 1986 年)

72 法堂がなかったわけではなく、応仁の乱の後に建てられた法堂が存在した ことは『鹿苑日録』天正十七年八月䀲日の条の入院上堂の記事上りわかる。

${ }^{73}$ 白石虎月編『東福寺誌』思文閣出版 1930 年初版 1979 年復刻

74 京都府教育委員会『重要文化財大徳寺経蔵及び法堂・本堂（仏殿）修理工 事報告畫』1982年

75 桜井累雄、南禅寺史』下 法藏館 1977 年

${ }^{76}$ 無著道忠『正法山誌』東林院 1935 年初版・思文閣 1975 年復刻

${ }^{37}$ 秋里啹岛著 安永九年 $(1780)$ 年开

${ }^{78}$ 『落凉軒日録』文明十九年四月十三日の条

${ }^{79}$ 大森健二『社寺建策の技術一中世を主とした歴史・技法・意匠一』（理工 学社 1998 年) は「複雜な構成より平明な架構が好まれてきた」という。

${ }^{80}$ 関口欣也「中世禅宗様仏堂の平面 (1)」日本建勧学会論文報告集第 110 号 1965 年

81 个重雕補註禅苑清規」第二巻上堂(前田慧需編『大日本続藏経』第 1 号 第 2 編 第 1.6 套第 5 冊)

${ }^{82}$ 竹貫元勝「概説 日本椫宗史 (四)」『禅文化』1.25㰾 1.987年

${ }^{83}$ 『鹿苑日録』慶最二年五月十二日の条に「則到沙喝、大鼻百十人在之」、 同じく十九日の条に「予引行道、大案百二十余、当寺之恤凡至沙喝百人」 とある。

84 「㭫前者謂法堂正面萁天柱之間也。按上堂凡有両次座前問訊」（無著道忠 『禅林象器篦』禮則門 誠信書房 1963 年) なお、推天柱とは「凡殿堂正 面左右二露柱」（無著道忠『禅林象器箋』殿堂門）

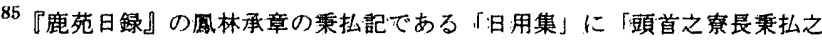
中、法堂正面東之柱ノ前二立也」などとある。

${ }^{86}$ 『鹿苑日録』文禄元年八月十三日の条、天瑞寺殿の法要が営まれ、五山、 大徳寺、妙心寺の僧が参列し大㖣の数が 700 人であったというから、相当 大きな客殿であったと思われる。

${ }^{87}$ 林田光椫編『智櫝院誌』(総本妆智䅡院 1915 年) 第五編 五、堂社伽藍 記

(2002年 9 月 24 .日原稿受理，2003年 3 月 12 日採用決定 $)$ 